\title{
LANGUAGE \& AUTHORITARIANISM IN THE 20TH CENTURY: THE CASES OF ESTONIA AND CATALONIA
}

\author{
Delaney Michael Skerrett
}

\begin{abstract}
The 20th century saw the Soviet and Francoist regimes enforce their respective ideologies in Estonia and the Catalan-speaking territories in Spain. In both cases, the autochthonous language suffered under the stringent control of the mechanisms of censorship and repression. In fact, Soviet and Spanish leaders-representing both extremes of the political spectrum-tried to replace the use of the autochthonous language in many sociolinguistic domains with their own-Russian and (Castilian) Spanish-as these languages embodied the ideologies and the new orders that they wished to establish. This paper compares and contrasts the diverse methods of control over language carried out in Estonia and the Catalan-speaking areas of Spain in order to demonstrate that highly centralised multilingual states-whatever their political ideology-can make use of surprisingly similar means of control, ultimately depriving local linguistic communities of the ability to use and develop their own language.*
\end{abstract}

Keywords: diglossia, languages in contact, language policy, language planning, endangered languages, Estonian, Russian, Catalan, Castilian Spanish, Spanish

\section{Introduction}

The Soviet and Francoist regimes are two salient examples of attempts by 2oth century authoritarian states to impose imperialistic linguistic policy as part of their political ideology. In both Soviet Estonia and the Catalan-speaking territories in Francoist Spain, the autochthonous language suffered under the stringent control of the mechanisms of censorship and repression. What is more, the leaders-from the extreme right in the Spanish case and the extreme left in the Soviet case-

* Acknowledgements. An earlier version of this paper was written in Spanish as a thesis at The University of 
attempted to replace the autochthonous variety in use in areas under their control in many domains with their own language: Russian in Estonia and Castilian Spanish in Spain. These languages embodied the ideologies and the new orders that they wished to establish. When authoritarianism came to an end and democracy was re-established, the sociolinguistic situation in these territories was one of diglossia, in which the vitality of Estonian and Catalan was threatened by the languages promoted by the Soviet Communists and the Spanish Fascists, respectively. This paper compares and contrasts the diverse methods of control over language carried out in Estonia and Catalonia in order to demonstrate that highly centralised multilingual states - whatever their political ideology-can make use of surprisingly similar means of control, ultimately depriving local linguistic communities of the ability to use and develop their own language.

\section{Authoritarian repression: The Francoists and the Soviets}

\subsection{Catalan and the Francoist ideology}

According to Hooper (1995: 413), Catalan suffered more under the Franco regime (1939-1975) than in any prior period of the history of the language, the fascists carrying out “a campaign [---] unparalleled in the region's history". Catalonia's autonomy ended with the region's occupation by Francoist forces (McRoberts 2001). In fact, the region itself was erased and it was divided into four provinces ruled directly by Madrid (Fishman 1991, May 2001). The leaders of Catalonia were killed or exiled (Keating 2001, Wright 1998). The Catalan language officially ceased to exist and was declared a "mere dialect" (Conversi 1997: 114, Fishman 1991: 297, Labanyi 1995, May, 2001: 242) of Castilian Spanish, "making use of a concept of 'dialect' belonging more to the 18th century than the 20th" (Moreno Fernández 2005: 228). With regard to use of their language, Catalan-speakers were told "we are in Spain,"2 "don't bark like a dog,"3 and "speak in Christian"4 (Ager et al. 1995, Azevedo 2005, Fishman 1991: 297, Mar-Molinero 2000, May 2001: 242, Strubell i Trueta (personal communication 2006), Sánchez \& Dueñas 2002). According to Moreno Fernández (2005: 228) "[i]f you are Spanish, speak the language of the Empire"5 was a catchphrase of the regime. This pressure to speak Castilian Spanish can be seen as part of Franco's "glorious national Movement" which had as one of its goals the substitution of Catalan with Castilian Spanish, "the language of the Empire"7 (Conversi 1997, May 2001: 242; McRoberts 2001: 41, Strubell 1998: 156). For Franco, Castilian Spanish was a symbol of "la Patria" ("the Homeland") and a singular Spanish national identity and the intention was thus to limit or indeed eliminate the other languages of the state (Mar-Molinero 2000: 84, Richards 1996, Shohamy 2006, Stewart 2002, Strubell i Trueta, Ros i Garcia 1984, Strubell 1998).

Conversi (1997: 109-110) maintains that "Francoism adopted the most radical politics of assimilation against non-Castilian cultures in modern Spanish history", according to which it was the responsibility of everyone to speak Castilian Spanish

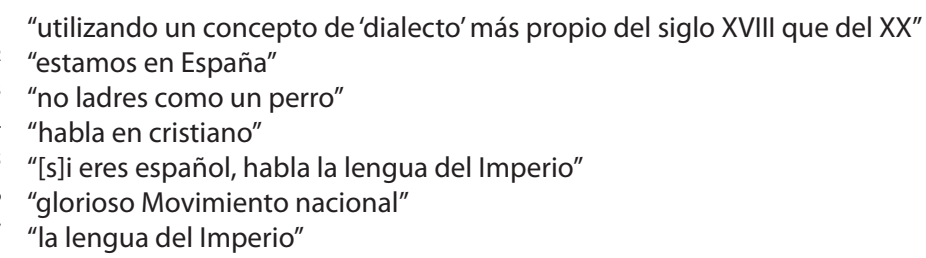


fluently, the language of "Hispanidad" (see also Richards 1996). As Wright (1998: 187, see also 2004) suggests, "[c]oercion and persecution were employed to achieve the goal of a strong, unitary state with a single language, a single history and a sense of a single tradition". The-now famous-declaration of the right-wing intellectual and Minister of Finance, José Calvo Sotelo, "Spain: better red than dead"8 reflects the major importance of-indeed, the obsession with-unity on the part of the Francoists (Conversi 1997: 109-110, Strubell 1998: 156). Their ideology of the united nation, furthermore, was imposed repressively in areas, such as Catalonia, that had been more regionalist (as well as more socialist (Wright 2004), evident in the term "red-separatist"9 (Conversi 1997: 110)). Richards (1996: 150) maintains that the regime constructed a binary ideological division between "Spain" and "antiSpain," according to which the only legitimate identity was the españolista, the patriotic one. Franco appropriated the symbols of 15th century Spain, the period of Ferdinand and Isabella: patriotic Spaniards (Castilian Spanish-speakers) were thus taking part in a crusade on behalf of "Christian civilisation," triumphing over "the malignant foreign powers" (Richards 1996: 150). The celebration of the discovery of the Americas as a Spanish victory over the non-Spanish and the non-Christians symbolised the Francoist victory over the separatist and non-Castilian peoples of Spain in general, or in other words, those "politically and morally poisoned elements" (Richards 1996: 158).

As was also the case under Soviet communism, praise was bestowed upon the social class considered to be the bearer of the ideological values of the new nation and, in this case, it was the Castilian farmers who possessed the true Spanish character (Richards 1996). Also similar to the Soviet case, myths were created so that people would believe in a new order-a "holy" empire and a common pastestablishing the necessary conditions to believe in the positive future (Richards 1996). The communists were of course atheists but the communist ideology assumed a religious quality (Lauristin, Vihalemm 1993). Militarism was highly valued: Franco established parallels between his "glorious triumph" and the historic victories of Felipe II and el Cid (who, significantly, had conquered Valencia, a Spanish region where a variety of Catalan is spoken); victory parades re-enacted those of the heroes of the Middle Ages (like el Cid); school texts set up a direct link between Franco and these historic victors (Richards 1996). At the same time, nonetheless, lies were propagated to establish the belief that, ultimately, the regime was peaceful in nature: the message of the 1959 documentary film, El camino de la paz (The Path of Peace), was that the Francoists, by way of the Civil War, had saved the Spanish people from the chaos of the previous times (Ellwood 1995).

The system of political propaganda, in both the Francoist and the Soviet cases, required the censorship and manipulation of the linguistic domains already in existence. In Spain, all books written in Catalan found in bookshops, public and private libraries, and publishing houses were destroyed (Hooper 1995, Labanyi 1995, Wright 1998). Pompeu Fabra's "priceless collection" (Hooper 1995: 413) of books was burnt in the streets-Fabra was a respected engineer and linguist who had established the norms for the restandardisation of the Catalan in 1913 (George 2002, Mar-Molinero 1996, Moldoveanu, 2002, Strubell 1996). In total, hundreds of thousands of books were destroyed, particularly in Barcelona (Conversi 1997, Strubell 1998). Publications, posters, and advertising in Catalan were banned, 
and all existing material was removed by the Fascists as part of their "hunt for the separatist" (Conversi 1997: 111); organisations that did not comply with the new regulations were closed and individuals could be (and were) dismissed, arrested, jailed, or fined (Conversi 1997, Fishman 1991, Mar-Molinero 2000, Wright 1998, 2004). Private correspondence was censored and often destroyed (McRoberts 2001). Censorship of the postal services lasted until 1948 (Conversi 1997). Other symbols of the local culture, besides language, were also done away with: the hymn and the flag of Catalonia were declared illegal and patriotic monuments and statues were destroyed (Conversi 1997, McRoberts 2001).

The names of cities and towns were Castilianised; the street of the Virgin of Monserrat (the patron saint of Catalonia) was renamed the street of the Redeemer and the Library of Catalonia became the Central Library (Hooper 1995, Labanyi 1995, May 2001). The use of Catalan was banned in all public spheres: in administration, commerce (including on labels), the press, on the radio, and (later) on television, as well as in education and in the Church; even private conversations between people in Catalan were considered dangerous (Ager et al. 1995, Conversi 1997, Fishman 1991, Hooper 1995, Keating 2001, Labanyi 1995, May 2001, McRoberts 2001, Sánchez, Dueñas 2002, Spolsky 2004, Strubell i Trueta, Ros i Garcia 1984, Strubell 1996, 1998, Wright 2004). "Barbarisms"-foreign borrowings into Castilian Spanish-were declared illegal (Labanyi 1995). All films had to be dubbed into Castilian Spanish: "stripped of any trace of dialects"10 (Labanyi 1995, Mar-Molinero 2000, Moreno Fernández 2005: 228). In the Basque Country, tomb stones written in Basque had to be replaced by the family of the deceased (Labanyi 1995). In terms of the language use of the Church, officially the Catalan Catholic hierarchy was in agreement with Francoist language policy, a position which "was in contradiction with the pastoral practices of the bilingual areas"11 of Spain, as the use of the autochthonous language "had been the norm since the 16th century"12 (Moreno Fernández 2005: 228). Although anti-Catalan bishops were sent to Tarragona, Lleida, Barcelona, and Tortosa, local priests never fully supported the dictatorship and the Church, in fact, would become an important factor in the opposition movement (Conversi 1997).

\subsection{Estonian and the Soviet ideology}

According to Raun (1985), the control over language in Soviet Estonia (1939-1941 and 1944-1991) contrasted sharply with the relatively liberal approach of the inter-war independence period (1918-1940). Although prescriptive grammars and dictionaries were not a new phenomenon, "[m]ore so than in the past the various dictionaries of correct usage [were] looked upon as the final word in linguistic matters, and through its central control of all publication the state [exerted] a powerful influence on the written language" (Raun 1985: 22, my emphasis).

Thus literature, fine arts (art was to serve an educative, not aesthetic purpose), education, research, theatre, cinema, exhibitions, advertising, all publicly accessible printed matter (down to public transport timetables, confectionary wrappers, tickets, postcards, and calendars), and even statistics were all targets for the propaganda machine and censorship (Lauk 1999, Lauristin, Vihalemm 1993: 180): "every social activity acquired symbolic meaning related to communist ideology.

\footnotetext{
10 "prescindiéndose, en absoluto, de los dialectos"

11 "entr[ó] en contradicción con la práctica lingüística de la acción pastoral en los territorios bilingües"

12 "había sido palmario en Cataluña desde el siglo XVI"
} 
Penetrating the minutest [sic] routines of everyday life, this ideology came to possess a religious character in Soviet society". The Soviet ideology thus formed the basis for control of all modes of expression: as all activities had meaning, these had to be regulated so that people would know how to behave in an appropriate manner, and the media in general, and journalism in particular, were to play a key role in educating the masses (Lauristin, Vihalemm 1993). As Lauk (1999: 19) states, "[t]he media were used for creating an alternative reality, 'an ideologically correct symbolic environment, filled with content designed to socialize the audience to the ideas and values of Communism"'. Officially, however, there was no censorship in the Soviet Union, and the constitution of the Estonian SSR, for example, guaranteed freedoms of speech and press to all citizens, with the provision that these freedoms be used for "the consolidation and development of the socialist order" (Põhiseadus, as cited in Lauk 1999). It was not until 1986 that Gorbachev admitted in an interview with a French communist paper that censorship existed in the Soviet Union (Lauristin et al. 1993).

Myths were also created to lead people to believe in the superior status of the Russian language. Clachar (1998: 108; see also Hogan-Brun et al. 2007) states that, beginning in the mid-1950s, strong pressure was placed on the non-Russian nationalities of the Soviet Union to become bilingual, and emphasis on Russian as the language of "international communication" was stepped up from the late 1950s; Khrushchev, and later Brezhnev, could be seen to be distancing Soviet ideology from the earlier "nationalist in form, socialist in content" thesis, which held some hope for the promotion of the titular languages, and the Russian language emerged as "one of [the regime's] strongest hallmarks". Khrushchev introduced new Soviet ideological catch phrases such as "[Russian as] second national language", "jazyk mezhnatsional'nogo obshchenija" ("language of international communication"), "dobrovol'no prinjatyi" ("voluntarily adopted"), "obshchij leksicheskij” ("common lexical fund"), and "vzaimoobogashchenie jazykov" ("mutual enrichment of languages") (Clachar 1998: 108), all to be achieved via "sblizhenie i slijanie natsii" ("convergence and fusion of peoples") (Knowles 1990: 150), with the result being "ravnopravie no ne vsegda ravnotsennost" ("equal rights but not always an equal share of esteem") (Knowles 1990: 154).

In 1978, the USSR Council of Ministers sent an unpublished decree of "recommendations" to the education ministers of the individual republics; the aim of the instructions was to implement measures to increase the use of Russian in public affairs and in education (Misiunas, Taagepera 1993, Ozolins 2000). The decree gave absolute primacy, more explicitly than ever before, to the Russian language: as Clachar (1998: 109-110) describes, it "went beyond the lingua franca" and was declared "the only means of active participation in social life". It set out language policy in various stages to "place social and psychological pressure on Estonians [and] other nationalities of the Soviet Union [---] to acquire Russian". These stages ranged from an initial monolingualism in the national tongue all the way through to complete bilingualism and, finally, post-bilingualism, in which Russian was to effectively become the "new native language".

Although Estonian continued to be used in less strategic domains by native speakers and did not completely disappear from public use as Catalan did, Russian was nonetheless to pervade further into cultural life: its usage was increased 
on radio and television, and even stipulated for increase in informal activities such as amateur theatre groups (Misiunas, Taagepera 1993). The increasing popularity of television of the time (a Latvian study found people were spending seven out of 20 weekly leisure hours watching television) only helped to further entrench Russification: in Estonia in 1975-76, 74\% of broadcasting was in Russian (Misiunas, Taagepera 1993). By 1980, out of an average of 35.3 hours of television shown on various channels per day in Estonia, 29.3 hours were in Russian (83\%) (Nørgaard et al.1996). At the 1980 Estonian song festival, all official speeches were made, for the first time ever, in Russian (Misiunas, Taagepera 1993).

Censorship of existing literature played an important role in the Soviet system (Lauk 1999). Schools, bookstores, and libraries were instructed to remove pages from non-fiction and fiction books alike (or get rid of the books altogether) that were considered to be inconsistent with Soviet ideology (especially those by "nationalist" authors) (Misiunas, Taagepera 1993). 70,00o books were burnt in the Tartu University library alone (Clachar 1998); in the first year of Soviet occupation, 200,000 copies of Estonian books were destroyed; during the years 1944-48, almost half a million books and periodicals were burned; from 1947, school libraries were cleansed over a five-year period, destroying over 25,00o books annually: estimates range from ten to twenty million copies of printed matter in total were disposed of in this "cleaning up" of libraries and bookstores, a process which continued until the 1960s (Lauk 1999: 21). By that time, more than $86 \%$ of all the books as well as all the periodicals published in independent Estonia were included on the lists of prohibited literature (Lauk 1999). Lists of banned Soviet literature also appeared and these books, too, were destroyed; books in foreign languages (for example Chinese and Japanese) were also destroyed as the acceptability of their contents could not be verified, given that the censors could not read them (Lauk 1999).

As in Catalonia, the Soviet authorities made use of politico-ideological renaming. Proper names, particularly place and street names were often changed (Raag 2003) - the examples in Russia are well-known (Leningrad and Stalingrad)-and the historic capital of Estonia's Saaremaa island was changed from Kuressaare to Kingissepa, after an Estonian communist (Taagepera 1993). Streets named after Soviet heroes abounded in Baltic cities. Ideological language was perhaps nowhere more evident than in the media, and it began with the very names of the publications: emphasising the communal nature of the Soviet people, their common future and commitment to communism.

\subsection{Immigration and the development of diglossia}

Russification in the sphere of language was significantly realised implicitly, within the framework of the massive state-controlled in-migration to Estonia (and Latvia), and, in all three Baltic states, the systematic process of deportation and terror. At least 700,000 people from the three countries were deported (Druviete 1997). In addition to this figure, we should consider the more than 250,000 who fled to the West, those who were outright killed by the occupiers (also including Nazi Germany during the Second World War), and those removed through Estonian and Latvian territorial loss (initially to the Russian SSR and to then the Russian Federation) (Kallas 2002, Parming 1978), to come to a total population loss for the three small 
Baltic states of approximately two million people: Misiunas and Taagepera (1993) estimate that in total Estonia lost $25 \%$ of its pre-World War Two population, Latvia 30\%, and Lithuania 15\%. Combined with the state-controlled in-migration (industrial workers, functionaries, Soviet military personnel as well as ex-convicts under the so-called 101 kilometre rule $^{13}$ ), and (later) personal spontaneous migration to the Baltic, the result was a massive fall in the autochthonous proportion of the population: the native Estonian population fell from $88.2 \%$ in 1938 to $74.6 \%$ in 1959 to approximately 60\% at independence (Lieven 1994). The city of Narva in north-east Estonia re-emerged after the war as exclusively Russian-speaking, due to a combination of migrant-staffed industrialisation and other immigration, and the fact that pre-war Estonian inhabitants were prohibited from returning to the area (Kallas 2002). These changes in the (ethno)linguistic makeup of the country, coupled with the privileged status given to Russian throughout the Soviet Union, meant that the language of everyday interethnic public communication in Estonia was Russian: a full set of public institutions was provided in Russian, while only a partial set was provided in Estonian (Adrey 2005, Clachar 1998, Nørgaard et al. 1996). Other non-native Russian-speaking immigrants to Estonia (chiefly Ukrainians and Belarusians) largely became Russian-speaking in the Soviet Estonian context as no public services were provided in their languages.

The sociolinguistic situation under authoritarianism-in both Estonia and Catalonia-can be classified as one of diglossia; as Hogun-Brun and colleagues (2007: 509) suggest, in the Estonian case, Russian enjoyed "an asymmetric hegemonic position”. Estonian, along with Latvian and Lithuanian, lost many vital and basic sociolinguistic functions within Soviet society, and the language hierarchy was clear: "in many everyday situations, the Balts [sic] were forced to speak Russian [---] The result was [---] the superior position of the Russian language" (Nørgaard et al. 1996: 178). As Adrey (2005: 458) states, "Russian was the exclusive dominant language in official spheres, i.e. state government, transport, industry, military, and in highly qualified employments and higher education, while Estonian and Latvian essentially channelled informal social communication". There was and to a certain extent still is, furthermore, the prevailing mindset of many Russian-speakers that they had "the right to be monolingual no matter where they live and work [in the (former) Soviet Union]" (Karklins as cited in Druviete 1997, Ozolins 1999: 181). In a 2003 survey, $16 \%$ of ethnic Estonians surveyed stated that they had used Russian with sales or service assistants in the last month; 8\% reported having done so with government employees (Vihalemm et al. 2004). Only 13\% of Russian-speakers in Estonia claim not to be able to speak Estonian at all, yet 27\% say they never use it (Vihalemm et al. 2004). Despite being public servants, a 2002 EU report found that there are still some police officers in Tallinn who "have virtually no command of Estonian" (Ozolins 2003: 27).

One of the main causes of sociolinguistic change-and the rise of diglossia-in Catalonia has also been immigration (especially that of 1959-72), and, just as in Estonia, the primary reason given for the immigration has been industrialisation and the lack of workers to implement it (Conversi 1997, Hooper 1995, May 2001), although some thinkers maintain that the Francoist and Soviet regimes used immigration as a premeditated tactic to dilute the autochthonous populations (Misiunas, Taagepera 1993, Wright 2004). In the 1950 s and 1960s, more than a million

13 "Under this rule, a person released from the prison could not settle nearer that $100 \mathrm{~km}$ from large cities, Leningrad 
Castilian Spanish-speakers arrived in Catalonia (McRoberts 2001). If we consider that around 200,000 fled the Catalan-speaking territories (Conversi 1997), we can appreciate the sociolinguistic changes that took place. The proportion of Catalanspeakers declined from 90\% in 1939 to 60\% of the population in 1975 (May 2001). During the post-war "years of development", Andalucians arrived to Catalonia in ever greater numbers, and although this was not the first mass immigration to the region, the Andalucians were the first who neither spoke Catalan nor had any historical relationship with Catalonia (Hooper 1995). As in Estonia, these immigrants had little incentive-or opportunity, for that matter-to learn the local language (May 2001). The Murcians, who had mostly arrived during the 1920s, had generally integrated into the Catalan society as Catalan had enjoyed widespread usage in the region and it was seen as a "language of social mobility" (Hooper 1995, May 2001: 243). An elderly Murcian who had given his eldest daughter the name Montserrat became a hero of the Catalan national cause (Hooper 1995).

The absence of the written use of Catalan (in other words, in formal domains and in the media), furthermore, created a situation in which many people could still speak the language but not read it or write in it; many more had difficulties reading the language as they were accustomed to an official written world which was completely Castilianised (Fishman 1991, Hooper 1995, Keating 2001, May 2001, Strubell i Trueta 1982, Strubell 1996). In 1979, among individuals born in Catalonia, only $\mathbf{1 9 . 2 \%}$ were able to write in Catalan; the figure for people born outside of the region was a miniscule 1.7\% (McRoberts 2001). Very few people were able to teach the language and civil servants had no experience whatsoever with its professional use (Strubell 1996). Furthermore, the home language of many Catalan-speakers was not Catalan: in cases in which Catalan-speakers were married to Castilian Spanish-speakers, the couple often used Castilian Spanish, given that both individuals could speak Castilian Spanish, but quite often the Castilian Spanish-speaker did not have a solid command of Catalan (Hooper 1995), this being particularly the case in Valencia (Strubell i Trueta 1982). Catalan, it should be noted, is not generally difficult for Castilian Spanish-speakers to learn (provided they have the motivation to do so) and many "immigrants" 14 to the region have at least a passive knowledge of the language (Mar-Molinero 1994, 1995), as opposed to the Estonian case, where Estonian (being a Uralic language) and Russian (being an Indo-European language) are not even from the same family.

As is the case with Russian in the former Soviet Union, Castilian Spanish enjoys a privileged social status according to which many native speakers of the previously imposed language believe they have the right not to use Catalan, even if they know the language; Catalans and Estonians, furthermore, often feel obliged to use Castilian Spanish and Russian, respectively (Druviete 2003, Lauristin, Heidmets 2002, McRoberts 2001, Strubell i Trueta 1982, Strubell 1996, Vihalemm et al. 2004). As Blas Arroyo (2005: 407) points out, in Catalan-speaking areas of Spain, and especially in the Eastern Fringe of Aragón, an area bordering Catalonia, Catalan can, "in switching to more formal domains as well as in conversation with strangers, be abruptly substituted by [Castilian] Spanish"15. In present-day Catalonia, a rather peculiar and perhaps surprising type of linguistic behaviour exists: two native-speakers of Catalan can speak to each other in Castilian Spanish without realising that the other speaks Catalan-a situation that has arisen due to 
the fact that the majority of Catalan-speakers speak unaccented Castilian Spanish, and they, in presuming that the interlocutor is a native Castilian Spanish-speaker, automatically choose that language (Strubell 2001). It should be made clear, nonetheless, that in neither of the cases presently discussed is it possible to speak of a low level of linguistic self-esteem among the autochthonous peoples, and it is precisely because of the solid language-based identities that these varieties were able to survive under authoritarianism (Conversi 1997, Doersam 1977). Sánchez and Dueñas (2002) assert that the linguistic minorities of Spain, in general, even achieved a certain prestige of their own as symbols of resistance to the authoritarian state. Blas Arroyo (2005: 408-409) asserts that Catalan "did not suffer significant linguistic loss despite the long Francoist interruption [---] either amongst native speakers or [---] the immigrants of Spanish-speaking origin"16. The fact that Catalan continued to be used during the dictatorship, albeit informally and unofficially, by people of higher socioeconomic groups has contributed to the association of the language with economic success, at least in Catalonia itself (Blas Arroyo 2005, Spolsky 2004). Nonetheless, as Conversi (1997: 117) asserts, "[i]n the 1950s there was a moment of real danger that Catalan would become a family language, extinct in the public sphere". Similarly, Hooper (1995: 416-417) claims that when, "Franco died, the Catalan language had entered a crisis [which] [---] if allowed to continue would sooner or later finish it off". Evald Mikkel, an Estonian political scientist (personal communication 2006) asserts that the Estonian language, in the 1980s, was verging on the "point of no return": Estonian-speaking parents had begun to send their children to Russian-medium schooling in the belief that it would be in their future best interest. If independence had not arrived when it did, and this trend had indeed continued and become consolidated, Estonian may have very well entered into an extremely precarious process of linguistic endangerment. Similarly, during the Francoist era, Catalan-speaking parents in Valencia would often speak to their children in Castilian Spanish; in that part of Spain the local variety had come "to be seen as mark of rurality and of people without culture"17, which has, naturally, affected its intergenerational transmission (Blas Arroyo 2005: 409). Of those that speak the Valencian variety today, up to one-third do not use it in many public contexts such as in shops, hospitals, or in spare time activities; in a study on the use of Catalan in the Eastern Fringe of Aragón in 1995, more than $80 \%$ indicated that they do not use the language in domains related to religion or health (Blas Arroyo 2005, Boix i Fuster, Vila i Moreno 1998).

\subsection{Languages in contact}

Strubell (2001; see also Wright 2004: 208) asserts that Catalan continues to be threatened by the influence of Castilian Spanish, decades after the death of Franco: "the danger exists that the specific characteristics of Catalan-in terms of phonetics, grammar, syntax, and vocabulary-will gradually be lost and that Catalan will become, in effect, a mere dialect of another language (Castilian Spanish)"18 (Strubell 2001: 277). This danger is owed to the fact that-unlike

\footnotetext{
16 "sufrió una merma significativa de prestigio pese el largo paréntesis franquista [---] tanto entre los hablantes nativos como [---] entre los inmigrantes de origen hispanohablante"

17 "interpretarse como marca de ruralidad [---] y de gentes sin cultura"

18 "[e]xiste el peligro de que las características específicas del catalán - en cuanto a la fonética, la gramática y la sintaxis, y al léxico - vayan perdiéndose gradualmente, y de que el catalán se esté haciendo, en efecto, un mero dialecto de otra lengua (el castellano)"
} 
countries such as the United States and Australia, in which immigrants have come from a variety of countries and thus have a variety of native languages-in Catalonia, the majority of immigrants are natively Castilian Spanish-speaking and the interference of Castilian Spanish is inevitable (Strubell 2001). In a very similar way, Russian-speakers make up the majority of immigrants in Estonia. The variety of Catalan spoken in Valencia has been influenced by Castilian Spanish to a much greater degree given the lesser presence of Catalan in the education system of that region, and the local colloquial language, in particular, includes hundreds of borrowings from Castilian Spanish (Strubell 2001). There is also an offensive term, catanyol, for "the process of hybridisation, through the influence of [Castilian] Spanish, in which Catalan is presently found, especially in the lowest sociolects"19 (Blas Arroyo 2005: 390), which attests to the quite significant interference of Castilian Spanish, at least among certain groups of Catalan speakers.

The form of Castilian Spanish spoken in Catalonia has also been influenced by Catalan; Blas Arroyo (2005: 386-387), for example, cites iya vengo! instead of iya voy! for the I'm coming of standard Castilian Spanish, and sácate (la chaqueta) instead of quitate (la chaqueta) for take off (your jacket), both expressions showing Catalan interference. It is not clear that this type of expression is habitual among native Castilian Spanish-speakers in the region, although Blas Arroyo indeed later notes that the use of the partitive, which does not exist in standard Castilian Spanish, as in the phrase, "me gusta el disco, pero los hay de mejores," "unlike other phenomena previously described, is not found among native speakers" ${ }^{20}$ (Blas Arroyo 2005: 556; see also Moreno Fernández 2005). The use of possessive phrases instead of prepositional ones, such as detrás mío instead of detrás de mí (Stewart 1999: 114) is also attributed to Catalan, as are morphosyntactic peculiarities such as "¿está la Julia?" (is the Julia there?) and "nadie no lo ha visto" ("nobody hasn't seen it"), and the lexical trait "voy derecho a Barcelona" for "I'm going straight to Barcelona" instead of directo, from the Catalan dret (Stewart 1999: 186). In terms of standard Castilian Spanish, it is now accepted-even by the country's main broadsheet $E l$ País-to use the Catalan spelling Generalitat, whereas previously Generalidad was used (Stewart 1999).

The influence of Russian on Estonian vocabulary has been substantial, although it was only the case during the Soviet period-prior influence had been from German and Finnish (Erelt 2003, Lieven 1994, Raun 1985). German has, in fact, significantly shaped Estonian: nearly one-third of Estonian vocabulary is of Germanic-language origin (Raun 1985, Viires 2004). The Soviet Russian-language influence could be seen as more insidious, however, given the planned and deliberately political nature of the changes. Loan translation or calques were the most common form of creation of new lexical items, examples being täitevkomitee ('executive committee'), viisaastakuplaan ('five year plan'), and lööktöö ('shock work') (Raun 1985). Direct borrowings also occurred but with less frequency than calques, although we can see examples such as kulak, narodnik ('a 19th century Russian socialist political term'), and oblast ('a particular administrative area') (Raun 1985); these were especially frequent where no metalinguistic equivalent existed (Knowles 1990, Vinay, Darbelnet 2004), meaning that the resultant Estonian-based term would be "either impossible or highly artifical [sic]" (Raun 1985: 24). There were occasions, however, where the official usage publication advocated the use of Estonian-based

\footnotetext{
19 "el proceso de hibridación en que se encuentra el catalán actual, por influencia del español [sic], especialmente entre los sociolectos más bajos"

20 "a diferencia de otros fenómenos reseñados anteriormente, no se detecta entre los monolingües"
} 
terminology when parallel forms existed: for example läbipääsuluba was to be used instead of propusk ('a pass') and särgik instead maika ('sleeveless shirt') (Raun 1985).

Raag (2003: 243) differentiates between the introduction of "fiction words" and "phenomena words" in Estonian. Fiction words were those that "project[ed] images devoid of any social basis in Soviet reality, and were used for propaganda reasons"; examples in Estonian include avangard ('vanguard'), idealism ('idealism'), demokraatlik tsentralism ('democratic centralism'), parteisisene demokraatia ('internal party democracy'), helge tulevik ('bright future'), kommunismi ehitamine ('the building of communism'), and töövalve ('watch of work'). On the other hand, phenomena words were those "denoting [novel but] real phenomena in the Soviet Union," such as the above terms for collective farms and the five-year plan, as well as autahvel ('honour board') (Raag 2003: 243).

There has, of course, been more "natural" influence between Russian and Estonian as well as the other titular languages of the Baltic states-mostly evidenced by the fact that Russian has adopted various direct borrowings and calques from Estonian, Latvian, and Lithuanian (Clachar 1998, Knowles 1990, 1999). Estonian Russian has seen the emergence of various linguistic forms, including lexical and morphosyntactic phenomena, apparently peculiar to that particular variety (Verschik 2004a, 2004b, 2005, 2006, 2007). Some of these, such as stavit'v golovu, (to put on [a hat]), are already, as Verschik (2007: 91) claims, "impossible in monolingual Russian" and "[f]or a monolingual speaker of Standard Russian [---] the meaning [---] remains opaque”.

\section{Conclusion}

Llobera (1996) draws a parallel between the national resistance in the Baltic countries under the Soviet Union and that which occurred in Catalonia. Citing Smith (1996a, 1996b), the author asserts that "nationalism had never disappeared, it had just taken other cultural forms" (Llobera 1996: 192). Mar-Molinero (2000: 85) notes on the Catalan case, although we could easily substitute Franco with Soviet, that

[---] the regime's clever propaganda drive made one costly mistake: the rejection and even ridicule of the [local] languages became so closely associated with the ideology of the Franco regime that it also served as a point of reference around which to build the opposition to it. Language became a symbolic standard bearer for and against the regime.

As Raag (2003: 249) maintains, however, official Soviet language use possessed "a general militaristic flavour. A progressive Soviet citizen did not walk or stretch his [sic] legs, but headed for or marched in lines to sing and dance" and these "militaristic traits did not disappear completely from Estonian lexicon as long as the occupation lasted". For years, the Catalans were not permitted to speak their language in public for fear of being fined, jailed, or simply being called a dog or unchristian. We can suppose that, although it was widely understood to be propaganda, censorship and manipulation ultimately influenced the language, culture, and society of the Estonians and the Catalans. In Latvia, the "high level of linguistic tolerance" (Druviete 
2003: 5) with Russian-speaking people even if they speak Latvian is proposed by Druviete (2003: 5) as part of the continuation of the "minority complex" formed during the Soviet period. This type of linguistic accommodation is certainly less frequent in Estonia but it still exists; in Catalonia it appears to be quite routine.

It seems to me, then, that the most serious sociolinguistic consequence of the Soviet and Francoist regimes is that related to the drastically reduced level of meaningful usage of the languages: severe restrictions in terms of what could be said and how it could be said impeded the development of cultural production in both Estonian and Catalan, thus impeding the languages themselves. In Catalonia and Estonia, the restriction of the usage of the autochthonous languages to particular domains did not allow these languages to develop along with the changing social conditions (May 2001). There was no corpus planning in Catalonia (Strubell 1996), while in Estonia it was restricted and prescriptive in nature (Hogan-Brun et al. 2007). And as Lauk (1999: 21) asserts, "Soviet censorship in Estonia clearly served the objective of Russification and destruction of Estonian national culture"; Francoism, as we have seen, had even more repressive goals towards Catalan-speakers.

Nevertheless, Estonian and Catalan survived in the face of authoritarianism and we can conclude that, in both cases, most people did not accept the officially sanctioned public usage of language and the related ideology. We can speak of two sociolinguistic worlds in Estonia, one official and Sovietised, the other unofficial and very much national in character (Vihalemm, Lauristin 1997). The Catalans also tenaciously maintained their cultural and linguistic worlds and, above all, "it must be recognised that [opposition to the dictatorship after some years] centered on [issues] of language and its recovery" (Conversi 1997: 137). The effect of highly centralised control of the national culture, and therefore also the language, however, should not be discounted. As Vihalemm and Lauristin (1997: 108) suggest-about the Baltic states but with clear relevance to post-Francoist Catalonia as well-"the unconscious adaptation to the Soviet cognitive and behavioural patterns that dominated in the spiritual environment of the Baltic people for decades [is] still quite large and [will remain] present for a long time [to come]".

\section{References}

Adrey, Jean-Bernard 2005. Minority language rights before and after the 2004 EU enlargement: The Copenhagen Criteria in the Baltic states. - Journal of Multilingualism and Multicultural Development, 26 (5), 453-468. doi:10.1080/01434630508668416

Ager, Dennis; Hoffman, Charlotte; Sala, Rafael; Radnai, Zsófia; Wright, Sue; Yates, Alan 1995. The debate. - Current Issues in Language and Society, 2 (1), 91-108.

Azevedo, Milton M. 2005. Introducción a la lingüística española. 2nd ed. Upper Saddle River, NJ: Pearson Education.

Blas Arroyo, José Luis 2005. Sociolingüística del español: Desarrollos y perspectivas en el estudio de la lengua española en contexto social. Madrid: Ediciones Cátedra.

Boix i Fuster, Emili; Vila i Moreno; F. Xavier 1998. Sociolingüística de la llengua catalana. Barcelona: Ariel.

Clachar, Arlene 1998. Differential effects of linguistic imperialism on second language learning: Americanisation in Puerto Rico versus Russification in Estonia. - International Journal of Bilingual Education and Bilingualism, 1 (2), 100-118.

Conversi, Daniele 1997. The Basques, the Catalans and Spain. Reno: University of Nevada Press. 
Doersam, Christopher 1977. Sovietization, culture, and religion. - Edward Allworth (Ed.). Nationality Group Survival in Multi-ethnic States: Shifting Support Patterns in the Soviet Baltic Region. New York: Praeger Publishers, 148-193.

Druviete, Ina 1997. Linguistic human rights in the Baltic states. - International Journal of Sociology of Language, 127, 161-185. doi:10.1515/ijsl.1997.127.161

Druviete, Ina 2003. The Latvian Language in the 21st Century. Riga: University of Latvia.

Ellwood, Sheelagh 1995. The moving image of the Franco regime: Noticiarios y documentales 1943-1975. - Helen Graham, Jo Labanyi (Eds.). Spanish Cultural Studies: An Introduction. The Struggle for Modernity. Oxford: Oxford University Press, 201-203.

Erelt, Mati 2003. Preface. - Mati Erelt (Ed.). Estonian Language. Linguistica Uralica Supplementary Series, 1. Tallinn: Estonian Academy Publishers.

Fishman, Joshua A. 1991. Reversing Language Shift: Theoretical and Empirical Foundations of Assistance to Threatened Languages. Clevedon, UK: Multilingual Matters.

George, David 2002. Institute of Catalan Studies. - Eamonn Rodgers (Ed.). Encyclopedia of Contemporary Spanish Culture. London: Routledge, 269-269.

Hogan-Brun, Gabrielle; Ozolins, Uldis; Ramonienè, Meilutė; Rannut, Mart 2007. Language politics and practices in the Baltic states. - Current Issues in Language Planning, 8, 469-631. doi:10.1515/ijsl.1997.127.161

Hooper, John 1995. The New Spaniards. London: Penguin Books.

Kallas, Kristina 2002. The formation of interethnic relations in Estonian SSR. (Unpublished MA Thesis.) Central European University, Budapest.

Keating, Michael 2001. Nations Against the State: The New Politics of Nationalism in Quebec, Catalonia and Scotland. 2nd ed. Houndmills, UK: Palgrave Macmillan.

Knowles, Francis 1990. Language Planning in the Soviet Baltic Republics: An Analysis of Demographic and Sociological Trends. - Michael Kirkwood (Ed.). Language Planning in the Soviet Union. New York: St. Martin's Press, 145-173.

Knowles, Francis 1999. Ethno-linguistic relations in contemporary Latvia: Mirror image of the previous dispensation? - Current Issues in Language \& Society, 6 (1), 48-56.

Labanyi, Jo 1995. Censorship or the fear of mass culture. - Helen Graham, Jo Labanyi (Eds.). Spanish Cultural Studies: An Introduction. The Struggle for Modernity. Oxford: Oxford University Press, 207-214.

Lauk, Epp 1999. Practice of Soviet censorship in the press: The case of Estonia. - Nordicom Review, 2, 19-31.

Lauristin, Marju; Heidmets, Mati 2002. Introduction: The Russian minority in Estonia as a theoretical and political issue. - Marju Lauristin, Mati Heidmets (Eds.). The Challenge of the Russian Minority: Emerging Multicultural Democracy in Estonia. Tartu: Tartu University Press, 19-30.

Lauristin, Marju; Vihalemm, Peeter 1993. The communist press in the Soviet Republics. Svennik Høyer, Epp Lauk, Peeter Vihalemm (Eds.). Towards a Civic Society: The Baltic Media's Long Road to Freedom. Perspectives on History, Ethnicity and Journalism. Tartu: Nota Baltica, 177-188.

Lauristin, Marju; Vihalemm, Peeter; Brikše, Inta; Bulota, Jonas; Dūze, Dace; Šulmane, Ilze 1993. The Period of Stagnation (1969-1986). - Svennik Høyer, Epp Lauk, Peeter Vihalemm (Eds.). Towards a Civic Society: The Baltic Media's Long Road to Freedom. Perspectives on History, Ethnicity and Journalism. Tartu: Nota Baltica, 211-220.

Lieven, Anatol 1994. The Baltic Revolution: Estonia, Latvia, Lithuania and the Path to Independence. 2nd ed. New Haven: Yale University Press.

Llobera, Josep R. 1996. The role of commemorations in (ethno)nation-building. The case of Catalonia. - Clare Mar-Molinero, Angel Smith (Eds.). Nationalism and the Nation in the Iberian Peninsula. Oxford: Berg, 191-206.

Mar-Molinero, Clare 1994. The politics of language: Spain's minority languages. - CLE Working Papers, 3, 106-113. 
Mar-Molinero, Clare 1995. The politics of language: Spain's minority languages. - Helen Graham, Jo Labanyi (Eds.). Spanish Cultural Studies: An Introduction. The Struggle for Modernity. Oxford: Oxford University Press, 336-342.

Mar-Molinero, Clare 1996. The role of language in Spanish nation-building. - Clare MarMolinero, Angel Smith (Eds.). Nationalism and the Nation in the Iberian Peninsula: Competing and Conflicting Identities. Oxford: Berg, 69-88.

Mar-Molinero, Clare 200o. The Politics of Language in the Spanish-speaking World: From Colonisation to Globalisation. London: Routledge.

May, Stephen 2001. Language and Minority Rights: Ethnicity, Nationalism and the Politics of Language. Harlow, UK: Pearson Education.

McRoberts, Kenneth 2001. Catalonia: Nation Building Without a State. Don Mills, Canada: Oxford University Press.

Misiunas, Romuald J.; Taagepera, Rein 1993. The Baltic States: Years of Dependence 1940-1990. Berkeley: University of California Press.

Moldoveanu, Mihail 2002. Noucentisme. - Eamonn Rodgers (Ed.). Encyclopedia of Contemporary Spanish Culture. London: Routledge, 367-368.

Moreno Fernández, Francisco 2005. Historia social de las lenguas de España. Barcelona: Ariel.

Nørgaard, Ole; Hindsgaul, Dan; Johannsen, Lars; Willumsen, Helle 1996. The Baltic States after Independence. Cheltenham: Edward Elgar.

Ozolins, Uldis 1999. Between Russian and European hegemony: Current language policy in the Baltic States. - Current Issues in Language \& Society, 6 (1), 6-47.

Ozolins, Uldis 2003. The impact of European Union accession upon language policy in the Baltic states. - Language Policy, 2, 217-238. doi:10.1023/A:1027320716791

Parming, Tönu 1978. Population changes and processes. - Tönu Parming, Elmar Järvesoo (Eds.). A Case Study of a Soviet Republic: The Estonian SSR. Boulder, CO: Westview Press, 21-74.

Raag, Virve 2003. Soviet Occupation and the Estonian Standard Language. - Anu Mai Kõll (Ed.). The Baltic Countries Under Occupation: Soviet and Nazi Rule 1939-1991. Stockholm: Department of History, Stockholm University, 241-250.

Raun, Toivo U. 1985. Language development and policy in Estonia. - Isabelle T. Kreindler (Ed.). Sociolinguistic Perspectives on Soviet National Languages: Their Past, Present and Future. Berlin: Mouton de Gruyter, 13-35.

Richards, Michael 1996. Constructing the nationalist state: Self sufficiency and regeneration in the early Franco years. - Clare Mar-Molinero, Angel Smith (Eds.). Nationalism and the Nation in the Iberian Peninsula: Competing and Conflicting Identities. Oxford: Berg, 149-167.

Sánchez, Aquilino; Dueñas, María 2002. Language planning in the Spanish-speaking world. - Current Issues in Language Planning, 3 (3), 280-305. doi:10.1080/14664200208668042

Shohamy, Elana 2006. Language Policy: Hidden Agendas and New Approaches. Milton Park, UK: Routledge.

Smith, Graham 1996a. Introduction: The Baltic nations and national self-determination. Graham Smith (Ed.). The Baltic States: The National Self-determination of Estonia, Latvia and Lithuania. New York: St. Martin's Press, 1-9.

Smith, Graham 1996b. The resurgence of nationalism. - Graham Smith (Ed.). The Baltic States: The National Self-determination of Estonia, Latvia and Lithuania. New York: St. Martin's Press, 121-143.

Spolsky, Bernard 2004. Language Policy. Cambridge: Cambridge University Press.

Stewart, Miranda 1999. The Spanish Language Today. London: Routledge.

Stewart, Miranda 2002. Language and national identity. - Eamonn Rodgers (Ed.). Encyclopedia of Contemporary Spanish Culture. London: Routledge, 293-294. 
Strubell i Trueta, Miquel 1982. Catalan sociolinguistics: A brief review of research. - International Journal of the Sociology of Language, 38, 70-84.

Strubell i Trueta, Miquel; Ros i Garcia, María 1984. Introduction. - International Journal of the Sociology of Language, 47, 5-11.

Strubell, Miquel 1996. Language planning and bilingual education in Catalonia. Journal of Multilingual and Multicultural Development, 17 (2-4), 262-275. doi:10.1080/01434639608666279

Strubell, Miquel 1998. Language, democracy and devolution in Catalonia. - Current Issues in Language and Society, 5 (3), 146-180.

Strubell, Miquel 2001. Catalan a decade later. - Joshua A. Fishman (Ed.). Can Threatened Languages be Saved? Reversing Language Shift, Revisited: A 21st Century Perspective. Clevedon, UK: Multilingual Matters, 260-283.

Taagepera, Rein 1993. Estonia: Return to Independence. Boulder, CO: Westview Press.

Verschik, Anna 2004a. Aspects of Russian-Estonian codeswitching: Research perspectives. - International Journal of Bilingualism, 8 (4), 427-448. doi:10.1177/136700 69040080040201

Verschik, Anna 2004b. Estonian compound nouns and their equivalents in the local variety of Russian. - Scando-Slavica, 50 (1), 93-109. doi:10.1080/00806760410011132

Verschik, Anna 2005. Russian-Estonian language contacts, linguistic creativity, and convergence: New rules in the making. - Multilingua, 24, 413-429. doi:10.1515/ mult.2005.24.4.413

Verschik, Anna 2006. Convergence in Estonia's Russian: Directional vs. static vs. separative verb. - International Journal of Bilingualism, 10 (4), 383-404. doi:10.1177/136700 69060100040101

Verschik, Anna 2007. Multiple language contact in Tallinn: Transfer B2 > A1 or B1 > A2? The International Journal of Bilingual Education and Bilingualism, 10 (1), 80-103. doi:10.2167/beb372.0

Vihalemm, Peeter; Lauristin, Marju 1997. Political control and ideological canonisation: The Estonian press during the Soviet period. - Eduard Mühle (Ed.). Vom Instrument der Partei zur "Vierten Gewalt": Die Ostmitteleuropäische Presse als Zeithistorische Quelle. Marburg, Germany: Verlag Herder-Institut, 103-109.

Vihalemm, Triin; Masso, Anu; Vihalemm, Peeter 2004. Eesti kujunev keeleruum. - Veronika Kalmus, Marju Lauristin, Pille Pruulman-Vengerfeldt (toim.). Eesti elavik 21. sajandi algul: ülevaade uurimuse Mina. Maailm. Meedia tulemustest. Tartu: Tartu Ülikooli Kirjastus, $57-73$.

Viires, Ants 2004. Old Estonian folklife. (Translated by Mart Aru.) Tallinn: Ilo Publishing House.

Vinay, Jean-Paul; Darbelnet, Jean 2004. A Methodology for Translation. (Translated by Juan C. Sager, M.-J. Hamel.) - Lawrence Venuti (Ed.). The Translation Studies Reader. 2nd ed. New York: Routledge, 128-137.

Wright, Sue 1998. Catalonia: The geographical and historical context of the language question. - Current Issues in Language and Society, 5 (3), 181-189.

Wright, Sue 2004. Language Policy and Language Planning: From Nationalism to Globalisation. Houndmills, UK: Palgrave Macmillan.

Delaney Michael Skerrett is a doctoral candidate in Applied Linguistics at The University of Queensland, researching Estonian post-Soviet language policy. He also lectures part-time in the Center for Baltic Studies and the Department of English at the University of Tartu. In 2009, he was invited to speak about the future of Estonian language policy and planning at the University of Barcelona.

d.skerrett@uq.edu.au 


\section{KEEL JA AUTORITAARSUS XX SAJANDIL: EESTI JA KATALOONIA JUHTUM}

\section{Delaney Michael Skerrett}

Queenslandi Ülikool, Tartu Ülikool

XX sajand nägi sovetlikku ja frankistlikku režiimi teostamas oma ideoloogiat Eestis ja Hispaania katalaanikeelsel territooriumil. Kummalgi juhul kannatas kohalik keel tsensori- ja repressioonimehhanismide jäiga kontrolli all. Tegelikult püüdsid Nõukogude Liidu ja Hispaania liidrid, esindades poliitilise spektri äärmusi, vahetada kohalikku keelt välja omaenese, vastavalt vene ja (Kastiilia) hispaania keele vastu, sest need keeled kehastasid ideoloogiat ja uut korda, mida nad soovisid kehtestada.

Artiklis võrreldakse Eestis ja Hispaania katalaanikeelsetel aladel keele üle kehtestatud kontrolli mitmesuguseid meetodeid ning näidatakse, et väga tsentraliseeritud mitmekeelsed riigid - olgu mis tahes poliitilise ideoloogiaga - kasutavad üllatavalt sarnaseid kontrollivahendeid, röövides äärmusena kohalikult keelekogukonnalt võim(alus)e kasutada ja arendada oma keelt.

Võtmesõnad: diglossia, kontaktkeeled, keelepoliitika, keelekorraldus, ohustatud keeled, eesti keel, vene keel, katalaani keel, Kastiilia hispaania keel, hispaania keel 